\title{
Identify patterns of individual dynamics of competitive performance of athletes as a basis for predicting results (qualified basketball players for example)
}

\author{
Kozina Zh.L. ${ }^{1}$, Gushchin S.A. ${ }^{1}$, Safronov D.V. ${ }^{2}$, Khrapov S.B. ${ }^{3}$, Vasilyev Yu.K. ${ }^{3}$ \\ ${ }^{1}$ Department of Olympic and Professional Sport and Sport Games, H.S. Skovoroda Kharkiv National \\ Pedagogical University, Ukraine \\ ${ }^{2}$ Department of Surgical Diseases and Topographic Anatomy of Kharkov National University, Ukraine \\ ${ }^{3}$ National Technical University "Kharkiv Polytechnic Institute" Kharkiv, Ukraine
}

\section{DOI: https://doi.org/10.34142/HSR.2019.05.02.04}

\begin{abstract}
The aim of the work wos to develop an algorithm and determine the patterns of the individual dynamics of the competitive performance of qualified basketball players.

Material and methods. The study involved the players of the main composition of the men's basketball team of Ukraine. It was analyzed 12 games of the national team of Ukraine in games with equal rivals - teams of other countries. The research was conducted from June 2018 to September 2018. Technical logging of games, which was carried out using a modified formula of Yu.M. Portnov. Mathematical modeling was used to describe the patterns of individual dynamics of competitive performance using sinusoidal regression models.

Results. The process of changing competitive performance should be considered in terms of oscillatory processes. The most acceptable function to describe this pattern is the sinusoidal function. The regression model of the individual dynamics of the effectiveness of competitive activity of the players of the Ukrainian basketball national team obeys a sinusoidal relationship, which is described by the sinusoidal regression equation.

Conclusions. The data obtained may be useful for predicting the individual game performance of athletes, determining the individual characteristics of players and adjusting training programs.
\end{abstract}

Keywords: basketball; dynamics; game; effectiveness; function; sinewave; individualization

\begin{abstract}
Анотація
Козіна Ж.Л., Гущин С.А., Сафронов Д.В., Храпов С.Б., Васильєв Ю.К. Виявлення закономірностей індивідуальної динаміки змагальної результативності спортсменів як основа для прогнозування результатів (на прикладі кваліфікованих баскетболістів)

Мета роботи - розробити алгоритм і визначити закономірності індивідуальної динаміки змагальної результативності кваліфікованих баскетболістів.

Матеріал і методи. У дослідженні взяли участь гравці основного складу молодіжної чоловічої збірної команди України 3 баскетболу. Було проаналізовано 12 ігор збірної команди України в іграх з рівними суперниками - збірними командами інших країн. Дослідження проводилося в період з червня 2018 року по вересень 2018 року. Технічне протоколювання ігор, яке проводилося за модифікованою формулою Ю.М. Портнова. Застосовувалося математичне моделювання для опису закономірностей індивідуальної динаміки змагальної результативності за допомогою синусоїдальних регресійних моделей. Результати. Процес зміни змагальної результативності доцільно розглядати з точки зору коливальних процесів. Найбільш прийнятною функцією для опису даної закономірності є синусоїдальна функція. Регресійна модель індивідуальної динаміки ефективності змагальної діяльності гравців збірної команди України з баскетболу підпорядковується синусоїдальної залежності, яка описується сінусоідальним рівнянням регресії.

Висновки. Отримані дані можуть бути корисні для прогнозування індивідуальної ігрової результативності спортсменів, визначення індивідуальних особливостей гравців і коректування тренувальних програм.
\end{abstract}

Ключові слова: баскетбол; динаміка; гра; результативність; функція; синусоїда; індивідуалізація

\section{Аннотация}

Козина Ж.Л., Гущин С.А., Сафронов Д.В., Храпов С.Б., Васильев Ю.К. Выявление закономерностей индивидуальной динамики соревновательной результативности спортсменов как основа для прогнозирования результатов (на примере квалифицированных баскетболистов)

Цель работы - разработать алгоритм и определить закономерности индивидуальной динамики соревновательной результативности квалифицированных баскетболистов.

Материал и методы. В исследовании приняли участие игроки основного состава молодежной мужской сборной команды Украины по баскетболу. Было проанализировано 12 игр сборной команды Украины в играх с равными соперниками сборными командами других стран. Исследования проводилось в период с июня 2018 года по сентябрь 2018 года. Техническое протоколирование игр, которое проводилось по модифицированной формуле Ю.М. Портнова. Применялось математическое моделирование для описания закономерностей индивидуальной динамики соревновательной результативности с помощью синусоидальных регрессионных моделей.

Результаты. Процесс изменения соревновательной результативности целесообразно рассматривать с точки зрения колебательных процессов. Наиболее приемлемой функцией для описания данной закономерности является синусоидальная функция. Регрессионная модель индивидуальной динамики эффективности соревновательной деятельности игроков сборной команды Украины по баскетболу подчиняется синусоидальной зависимости, которая описывается синусоидальным уравнением регрессии

Выводы. Полученные данные могут быть полезны для прогнозирования индивидуальной игровой результативности спортсменов, определения индивидуальных особенностей игроков и корректировки тренировочных программ.

Ключевые слова: баскетбол; динамика; игра; результативность; функция; синусоида; индивидуализация 


\section{Introduction}

"To foresee is to control" [1], - Pascal's aphorism applies to all controlled systems, including the process of sports training. Foresight involves making forecasts and adjusting training programs according to the results obtained, since the prediction of the future is a chance to change it, it is "the choice of those who want to win time" [1], i.e. rise to a higher level in any kind of activity. It is not by chance that, as long as humankind exists, so much does people have a passionate desire to look into the future. Existed and there are a huge number of predictors and ways to predict the future $[2,3]$. There are also scientific methods of forecasting, the algorithms of which are applicable to many types of human activity, including the process of sports training $[4,5]$.

Forecasting is an integral part of managing any process, including the process of preparing athletes, since the goal in sports is to overcome one's own limitations, raising one's functional state to a new level.

What is needed to make high-quality forecasts? Turn to the classics to answer this question. For example, Belinsky [1] wrote: "Without knowing the past, it is impossible to understand the present and it is impossible to foresee the future", thereby emphasizing the need for a detailed analysis of current events in order to manage any process in the present and in the future. This statement coincides with the opinion of Gurdjieff [1]: "If a person has thoroughly studied what happened yesterday, the day before yesterday, a week, a year, ten years ago, he will be able to accurately say what will happen and what will not happen tomorrow."

It should be noted that the methods of scientific forecasting are closely intersected with the statements of the classics of culture. For compiling scientific forecasts in economics and sociology, many authors [2, 3] recommend the following algorithm: 1. Collect data on similar events in the past. 2. Search for patterns in the events that have occurred. 3. Extrapolation of the obtained laws to the future and making forecasts. 4. Preparation of recommendations to adjust the alleged events.

The basis of sports forecasts is also the analysis of patterns of similar events of the past, therefore, in order to predict an individual competitive performance of an athlete, it is necessary to find patterns of the dynamics of his competitive performance in the past.

In this regard, the definition of patterns of individual dynamics of competitive performance will allow you to optimize the training process through the regulation of the level of load and recovery activities according to the obtained laws.

The aim of the work is to develop an algorithm and determine the patterns of the individual dynamics of the competitive performance of qualified basketball players.

\section{Material and methods}

\section{Participants}

The study involved the players of the main composition of the men's basketball team of Ukraine. It was analyzed 12 games of the national team of Ukraine in games with equal rivals - teams of other countries.

\section{Research organization}

The research was conducted from June 2018 to September 2018. Technical logging of games, which was carried out using a modified formula of Portnov [6]. Mathematical modeling was used to describe the patterns of individual dynamics of competitive performance using sinusoidal regression models.

\section{Statistical analysis}

To describe the patterns of individual dynamics of competitive performance was applied sinusoidal regression analysis.

The use of a regression sinusoidal model is effective in practical work, since it allows you, quite quickly, using only data from technical reports, to predict the time of "ups" and "recessions" of individual game performance. This helps to adjust training programs, for example, by reducing the level of physical exertion before the expected "recession" or paying more attention to the means of recovery.

The main indicator in the sinusoidal formula for practical work is the period of oscillation. Knowing the period of individual fluctuations of the athlete's functional state, which determines the game performance, the coach can foresee the "ups and downs" of the competitive performance of each player.

\section{Results}

Theoretical substantiation of the sinusoidal model of individual dynamics of competitive performance. From the classical theory of sports [7, $8,9]$ it is known that the development of sports form is carried out in waves, with certain limited periods of linear development. For practical work and prediction of results over short time intervals, linear regression models are used [10, 11, 12]. However, it 
is already difficult to describe the longer periods of development of sports by the linear regression equation, for this it is necessary to apply other functional patterns.

One of such functional patterns is oscillatory processes [13, 14]. According to physical laws, oscillations are motions or processes that have one or another frequency in time. For living systems, harmonic oscillations are most characteristic, in which the oscillating quantity $\mathrm{x}$ varies with time according to the law of sine or cosine (Fig. 1):
$x(t)=A \cdot \operatorname{Cos}(\omega t+\alpha)$,

or

$\mathrm{x}(\mathrm{t})=\mathrm{A} \cdot \operatorname{Sin}(\omega \mathrm{t}+\alpha)$

where:

A - the amplitude;

$\omega$ - the circular frequency;

$\alpha$ - the initial phase;

$(\omega t+\alpha)$ - phase.

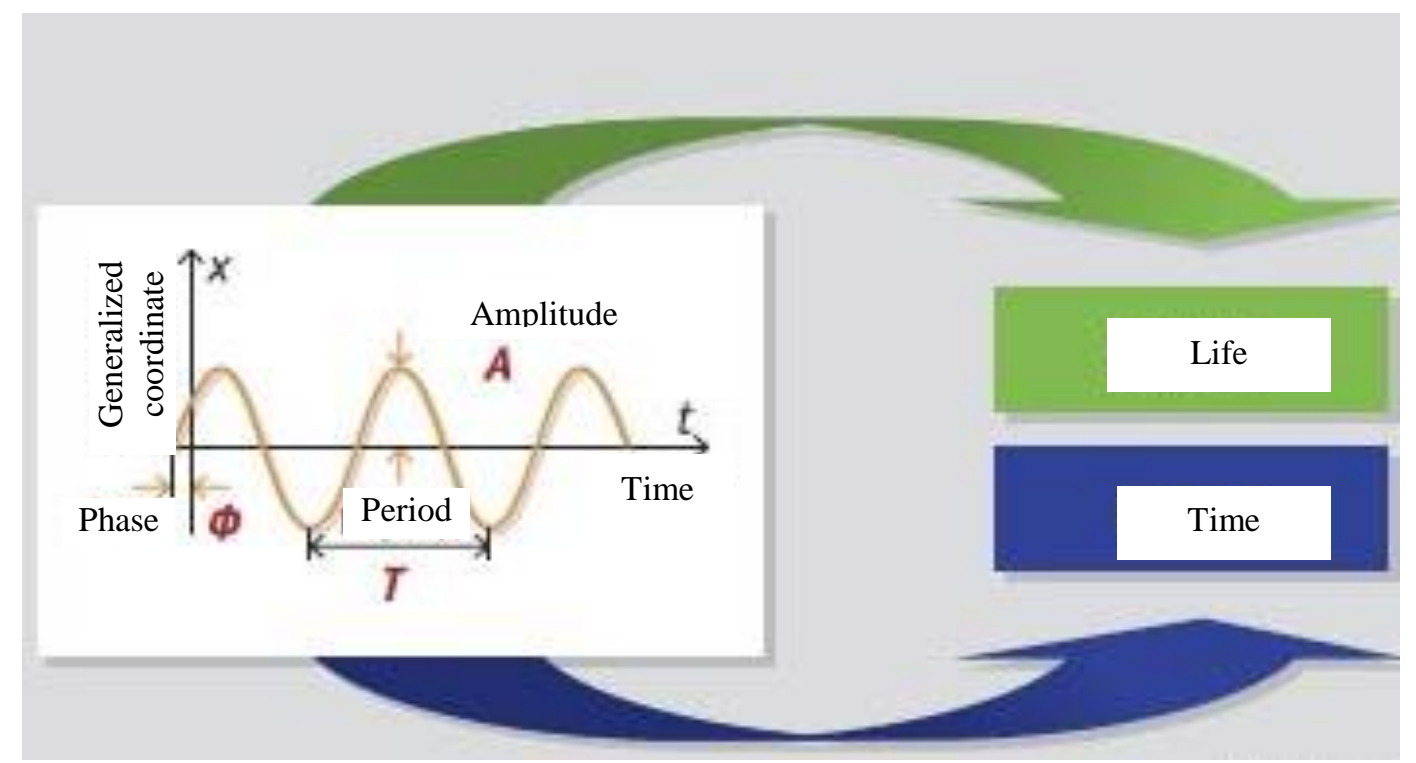

Fig. 1. Graph of harmonic oscillations in living systems [14]

Oscillatory processes occurring in nature, determine the biological time. In nature, there are countless various oscillatory processes. There are oscillatory processes that occur at the cell level, the time of which is measured from 0.5 minutes to an hour.

There are oscillatory processes that occur at the level of individual body systems. For example, heartbeat, breathing, changing phases of sleep and wakefulness, fluctuations in body temperature (higher in the day), muscle function of the intestines, metabolic rate, degree of activity and speed of reactions, mood, etc. Even the size of the cells themselves have different periods of oscillation.

Part of this kind of oscillatory processes has a circadian (near-day) cycle. Another part of the processes occurring at the level of individual systems has cycles corresponding to the change of the phases of the moon. These are either lunar-monthly cycles equal to about 29.5 Earth days, or lunar-diurnal cycles equal to lunar days (approximately 24.8 Earth hours). There are also fluctuations with a frequency equal to the cycles of sea tides (24.8 or 12.4 hours).
There are oscillatory processes with an annual cycle of functional activity of the organs [14].

Oscillatory processes occurring in nature are the main condition for the preservation of life on Earth, and the existence of biological time is a tough necessity: outside of its own biological time, all life could neither exist nor reproduce [14].

In this regard, the process of changing competitive performance, which is one of the aspects of biological processes, it is advisable to consider in terms of oscillatory processes. Therefore, if we consider the dynamics of competitive performance of athletes, then the most acceptable function to describe this pattern is a function that reflects harmonious oscillatory processes, i.e. - sinusoidal.

Sinusoidal models of individual dynamics of competitive performance. As shown by our experimental studies [11, 12, 13, 15], the most adequate model for describing the individual characteristics of the dynamics of competitive performance is the sinusoidal function, since the changes in these indicators are harmonious, i.e. are described by sinusoidal functions with a period of 25-30 days for women and 33-37 days for men and 
have a significant correlation $(r=0.53-0.71, p<0.05)$ with the values of the emotional biological rhythm for women and intellectual biorhythm in men [eleven]. The use of these patterns in the training process had a positive impact on the performance of individual competitive performance and functional state of athletes [11].

The use of a regression sinusoidal model is effective in practical work, since it allows you, quite quickly, using only data from technical reports, to predict the time of "ups" and "recessions" of individual game performance. This helps to adjust training programs, for example, by reducing the level of physical exertion before the expected "recession" or paying more attention to the means of recovery.

The main indicator in the sinusoidal formula for practical work is the period of oscillation. Knowing the period of individual fluctuations of the athlete's functional state, which determines the game performance, the coach can foresee the "ups and downs" of the competitive performance of each player.

In our previous works $[11,12,13]$, we performed identification of sinusoidal regression coefficients using the MathCAD program, however, for practical work of a trainer, work in the MathCAD program is not always available, therefore we applied the sinusoidal regression building algorithm in the ECXEL program ", Which is described in detail in $[12,13,15]$.

It should be noted that the identification of patterns of individual competitive performance is appropriate only for qualified athletes, since the higher the level of qualification, the more ordered is the pattern of changes in individual competitive performance.

For example, we want to know whether any individual patterns are subject to the individual dynamics of the competitive performance of the players of the Ukrainian national team. To do this, you can use the data of the technical reports on games with the main rivals of the Ukrainian team for a certain period of time (the minimum period is 3-4 months). Modern technical reports in teams of the highest league, super league and national teams of the country are usually compiled using computer programs, which facilitates data processing [16].

To determine the individual patterns of the dynamics of competitive performance, we recommend using such an indicator as "the sum of positive points in the game", which most accurately reflects the level of the player's "positive" contribution to the result of the meeting. You can also use any other indicator, the most significant for a particular player, for example, the indicator of the total number of points brought by the player, or the number of rebounds.

In our case, we analyzed the dynamics of the index of individual game performance of individual players of the Ukrainian team in 12 games during the 3 months of 2018 (June-August). As a result of the analysis of the obtained sinusoidal model, it was revealed that the regression model of the individual dynamics of the effectiveness of competitive activity of the players is subject to sinusoidal dependence. For example, for player 1, this pattern is described by the regression equation (Fig. 2):

$$
S+=12+11 \sin ((2 \pi / 28)(T-27)),
$$

where:

S+ - the number of "positive" points;

$T$ - time interval, that is, the day in a row from the first game to be analyzed.

Coefficient 12 means the average performance of the player, the coefficient 11 means the amplitude of the game performance fluctuations of the athlete, factor 28 - the period of the game performance fluctuations of player 1, coefficient 27 the value of the period at the time of the first game being analyzed.

For the practical work of the coach, the most important is the indicator of the fluctuation period of the game performance of each player. In this case, the oscillation period of the game performance of a basketball player is 28 days. This means that if this athlete has a pronounced rise in game performance for a certain period of time, a similar rise can be expected after about 28 days, and after 14 days we can expect a relative decline in the player's functional state. By reducing the load before the expected "recession" or using adequate means of restoring performance, it is possible to significantly reduce the "recession" and increase the "rise" $[11,15]$. In our case, player 1 should have had a "boost" of competitive performance (or functional state) 28 days after the last "lift" according to a sinusoidal function, i.e. 3.09.2018, 1.10.2018, which is confirmed by the results of its competitive activity. At more remote intervals, the forecast may not work due to the large number of influencing factors. You can check the results of the forecast by analyzing the game performance (or functional state) of the athlete at these intervals of the time $[11,15]$. 


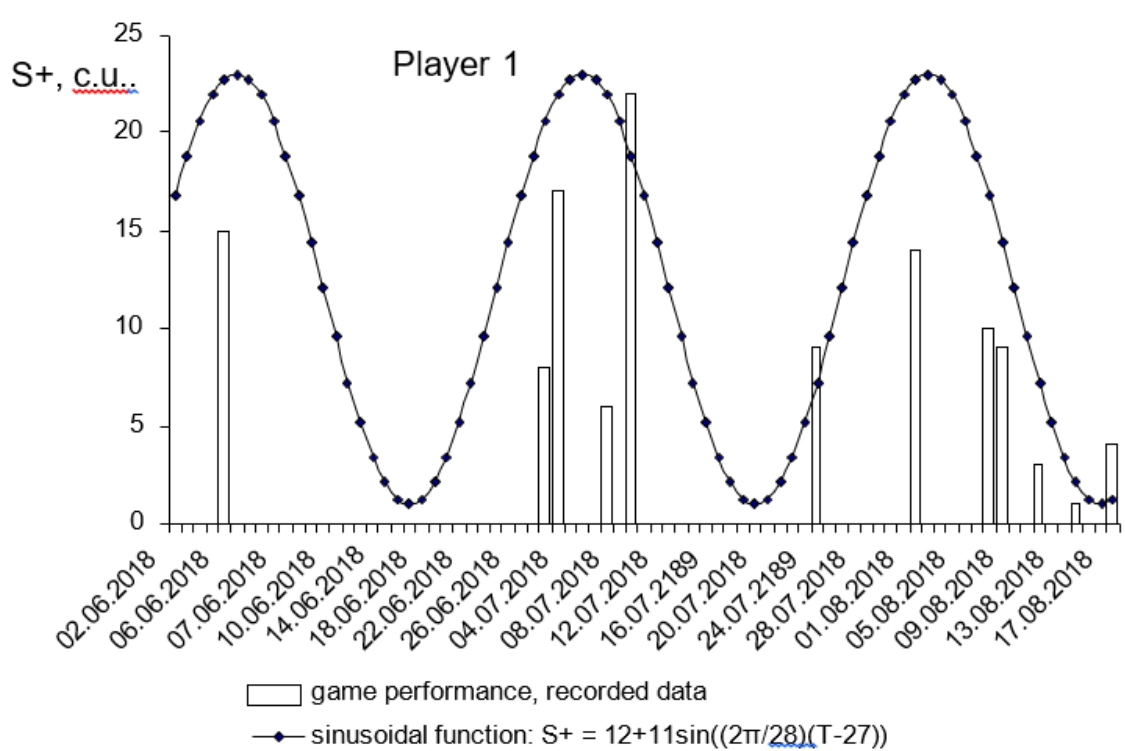

Fig. 2. Dynamics of individual game performance of a basketball player of the Ukrainian team (player 1)

Consider the patterns of individual dynamics of the competitive performance of another player of the Ukrainian team, player 2. The regression model of the individual dynamics of the competitive activity of this athlete is also subject to a sinusoidal relationship (Fig. 2), which is described by the regression equation

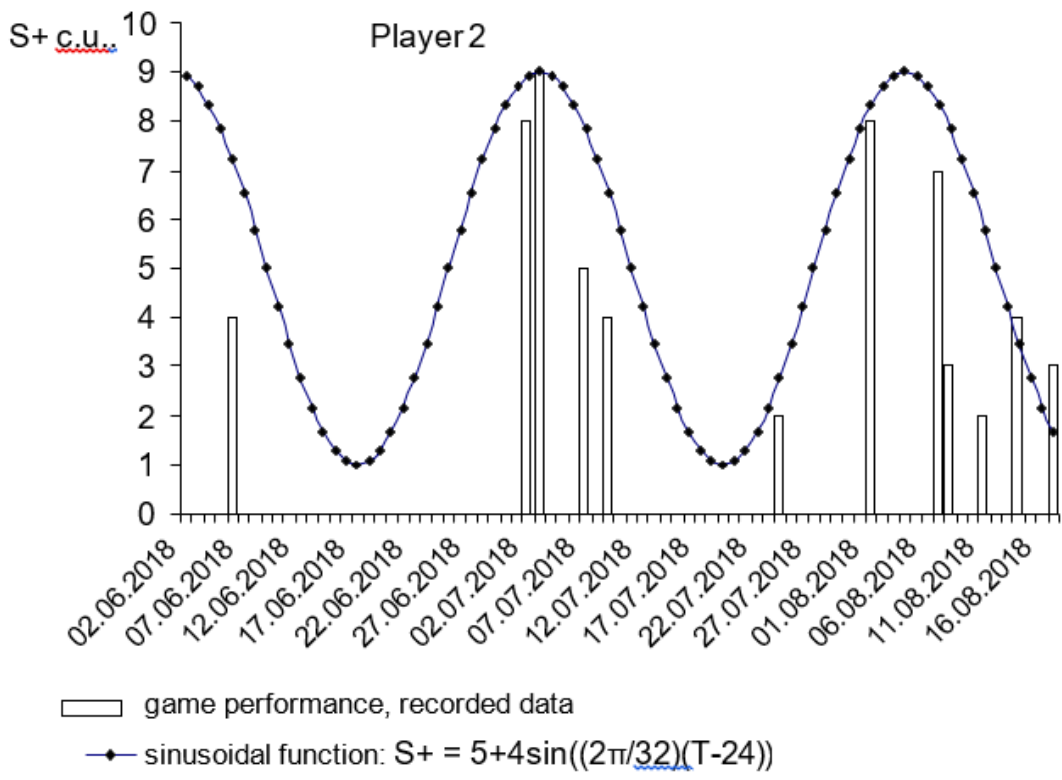

Fig. 3. Dynamics of individual game performance of a basketball player of the Ukrainian team (player 2)

$S+=5+4 \sin ((2 \pi / 32)(T-24))$,

where:

S+ - the number of "positive" points;

$T$-time interval, that is, the day in a row from the first game to be analyzed.

Coefficient 5 means arithmetic average value of the game performance of this player, coefficient 4 means the amplitude of the game performance fluctuations of the athlete, coefficient 32 - the period of fluctuations of the game performance of the athlete
2, coefficient 24 - the value of the period at the time of the first analyzed game.

The period of fluctuations in the game performance of a basketball player 2 is 32 days. Extrapolating the data obtained, we find that player 1 had to have a "rise" of competitive performance (or functional state) 32 days after the last "lift" according to a sinusoidal function, i.e. 09/06/2018, 10/8/2018, which is also confirmed by the results of his competitive activities in this period. 


\section{Discussion}

Based on the obtained results and literature data $[2,3,4]$, it is possible to determine the individual characteristics of the analyzed players and, accordingly, of similar types of players.

For example, for an athlete, 1 period of fluctuations in game performance is 28 days. Based on the literature data on the psycho-physiological features of people with different biorhythm periods $[17,18,19]$, it can be concluded that this athlete's general condition, and, consequently, his competitive performance, depends on the physical biorhythm [20, $21,22]$. As shown by our previous studies [15], for many qualified basketball players, the dynamics of game performance is determined by the psychological state, but player 1 is distinguished by the fact that its game performance determines precisely the physical state. The decisions that a player makes on the court and in life are also determined by his physical condition. In this regard, it is logical to conclude that for this player the best means of recovery will be massage, including vibratory massage, sauna. As a means of recovery for player 1 can also be used funds from other sports and activities, such as fast dancing, such as Hispanic, downhill skiing, which, however, requires caution. Athlete 1 may have a tendency to hypertension, therefore, due attention must also be paid to natural relaxation means, such as medicinal plants, such as peppermint (Méntha piperíta), coltsfoot (Tussilágo), and oak (Quércus róbur), yarrow (Achilléa millefólium), blood-red hawthorn (Crataégus sanguínea), heart-leaved linden (Tília cordáta), etc. $[26,27]$.

Player 2 has a period of fluctuations in game performance of 32 days. Based on the literature data on the psycho-physiological features of people with different biorhythm periods $[23,24,25]$, it can be concluded that this athlete's general condition, and, consequently, his competitive performance, depends on the psychological state, on his inner world. The obtained data are in line with our previous studies [15], which showed that in qualified basketball players, the game performance correlates with the values of the intellectual biological rhythm. In this regard, this player first needs to understand the meaning of the proposed exercises, "play" in the mind various technical and tactical actions. For player 2, independent installations for activating recovery processes and increasing mutual understanding with partners and coaches are also very effective. In addition, for player 2 , being in a nature zone is useful. This player is suitable as a means of recovery for calm music, such as "relax" or "trance" with video accompaniment. Of all other sports, everything that is connected with the need to think is suitable: other sports games, martial arts. As a medicinal plant, it is possible to use toning and strengthening the nervous system to increase and restore working capacity: Ginseng (Pánax), Cornflower (Centauréa jacéa), Chamomile (Matricāria chamomīlla), Origanum Orientanum (Oríganum vulgáre), British Devilsil (Pentanéma británnicum), Inula hirta (Ínula), Calamus (Ácorus cálamus), and others [26, 27].

\section{Conclusions}

1. The process of changing competitive performance should be considered from the point of view of oscillatory processes. The most acceptable function to describe this pattern is the sinusoidal function.

2. The regression model of the individual dynamics of the effectiveness of competitive activity of the players of the Ukrainian basketball national team obeys a sinusoidal dependence, which is described by the regression equation $\mathrm{S}+=\mathrm{a}+\mathrm{b} \sin ((2 \pi /$ t) (T-c)), where $S+$ is the number of "positive" points, $\mathrm{T}$ is the time interval, that is, the day in a row from the first game being analyzed, the coefficient a means the average value of the game performance of a given player, the coefficient $b$ means the amplitude of fluctuations of the game performance of an athlete, the coefficient $\mathrm{t}$ is the period $\mathrm{k}$ oscillations gaming performance athlete coefficient $\mathrm{c}$ - meaning a period of time of the first analyzed games.

3 . The use of a regression sinusoidal model is effective in practical work, as it allows quite quickly, using only the data from technical reports, to predict the time of "rises" and "recessions" of individual game performance, which helps to adjust training programs and determine some psychophysiological individual characteristics of players.

\section{Acknowledgements}

The study was conducted in accordance with the research work of Ministry of Education and Science of Ukraine for 2019-2020 «Theoretical and methodological foundations of technology development for the restoration of musculoskeletal system and functional state and prevention of injuries and representatives of different age groups in physical culture and sports» (№ 0119U100634).

\section{Conflict of interest}

The authors state no conflict of interest. 


\section{References}

1. Aphorisms, quotes and popular words. Access mode: http://aphorism-

list.com/autors.php?page $=$ belinskiy \& tkautors $=$ belinsk iy. In Russian

2. Bondarenko AV. Refinement of the sales forecasting algorithm. [Electronic resource]. Access mode: http://www.cfin.ru/finanalysis/math/add to_kosh.sht ml. In Russian

3. Zaginaylo IV. Periodic trend lines in forecasting sales [Electronic resource]. Access mode: http://www.cfin.ru/finanalysis/math/add_to_koshbond.shtml. In Russian

4. Koshechkin SA. Algorithm for forecasting sales in MS Excel. [Electronic resource]. Access mode: http://www.cfin.ru/finanalysis/sales forecast.shtml. In Russian

5. Matveyev LP, Hasanova FOR Testing a single hypothesis and commenting on it in the aspect of the theory and practice of sports. Theory and Practice nat. culture. 2001; 5: 2-11. In Russian

6. Kozina Z. Factor models of the physical preparedness of volleyball players of a high class of various game role. Pedagogy, Psychology and medical and biological problems of physical education and sport, 2007;9: 80-85.

7. Kozina ZL, Cieslicka M, Prusik K, Muszkieta R, Sobko IN, Ryepko OA, Bazilyuk TA, Polishchuk SB, Osiptsov AV, Korol SA. Algorithm of athletes' fitness structure individual features' determination with the help of multidimensional analysis (on example of basketball). Physical education of students. 2017;21(5):225-

238http://dx.doi.org/10.15561/20755279.2017.0505

8. Platonov VN. The general theory of training athletes in the Olympic sport. K .: Olympic literature, 1997: 584. In Russian

9. Platonov VN. Periodization of sports training. General theory and its practical applications. K.: Olympic literature, 2013: 624 p. In Russian

10. Dykyi BV, Ilko AV. Having infused young-sonic rhythms to the human health camp. Science Bulletin of Uzhgorod University. Ser .: Medicine, 2001;16:107112. In Ukrainian

11. Kozina ZhL, Voskoboinik AC, Grin LV. Application of methods of multidimensional and nonlinear regression analysis to reveal the laws of individual dynamics of competitive performance in basketball. Health, sport, rehabilitation. 2015;1:40-42. In Russian

12. Kozina ZL, Jagiello Wladyslaw, Jagiello Marina. Determination of sportsmen's individual characteristics with the help of mathematical simulation and methods of multi-dimensional analysis. Pedagogics, psychology, medical-biological problems of physical training and sports, 2015;12:41-50. http://dx.doi.org/10.15561/18189172.2015.120

13. Kozina Zh.L., Prokopenko I.F., Cretu M., Chebanu O.I., Ryepko O.A., Osiptsov A.V., Razumenko T.O. Individual chronobiological regularity in track-andfield sprint. Pedagogics Psychology MedicalBiological Problems of Physical Training and Sports. 2018, 22(3).
https://sportpedagogy.org.ua/index.php/PPS/pages/vie $\mathrm{w} / \mathrm{next}$

14. U-Journal: Time and life as a form of oscillatory process. [Internet site]. Access Mode: http://www.ujournal.com/sections/time/1(7)/10/. In Russian

15. Kozina ZhL, Zaschuk SG, Grin LV, Conformities to law individual dynamics of playing effectiveness of basketball-players of collapsible command of Ukraine. Physical Education of Students. 2010;1:52 - 56.

16. Kozina Zh.L., Ol'khovyj O.M., Temchenko V.A. Influence of information technologies on technical fitness of students in sport-oriented physical education. Physical education of students, 2016;1:21-28. http://dx.doi.org/10.15561/20755279.2016.0103

17. Ali G. Loads of Training Geared to the Pattern of Daily BioRhythm on Some Vital Functions and Development of 800-meter Runners. World Journal of Sport Sciences. 2010; 3 (S): 1250-1254.

18. Araujo LG. Waterhouse J., Edwards B. Henrique E., Santos R., Tufik S., Túlio de Mello M. Twenty-fourhour rhythms of muscle strength with a consideration of some methodological problems. Biological Rhythm Research. 2011; 42(6): 473-490.

19. Bardis K, Atkinson G. Effects of time of day on power output and thermoregulation responses during cycling. Biology of exercise. 2008; 4:17-28.

20. Hines TM. Comprehensive review of biorhythm theory. Psychology Department, Pace University, Pleasantville, NY. Psychol Rep. 1998 Aug;83(1):1964

21. Shaffer JW., Schmidt CW., Zlotowitz HI., Fisher RS. Biorhythms and Highway Crashes. Are They Related? Arch Gen Psychiatry. 1978;35(1):41-46.

22. Bessot N, Moussay S, Clarys JP, Gauthier A, Sesboüé B, Davenne D. The influence of circadian rhythm on muscle activity and efficient force production during cycling at different pedal rates. J. Electromyogr. Kinesiol. 2007; 17: 176-183.

23. Chaâri N, Frikha M, Mezghanni N. Time-of-day and warm-up durations effects on thermoregulation and anaerobic performance in moderate conditions. Biological Rhythm Research. 2013; 10: 46-49.

24. Sokolova VS, Dvornikov PA. Biorithms and their influence on the effectiveness of the training process and the results of competitions of the competitionbiathlonists // Modern problems of science and education. 2015; 4:36-42.

25. Shafiee S, Rahim R, Hakime A, Vahid R. The relationship between biorhythm (physical cycle) and sports performance in women's basketball. Physical education of students, 2016;3:58-64. doi:10.15561/20755279.2016.030

26. Pandey A, Gulati S, Gupta A, Tripathi Y. Variation in andrographolide content among different accessions of Andrographis paniculata. The Pharma Innovation Journal, 2019;8(4):140-144.

27. Tripathi P, Tripathi Y. Physicochemical and Nutritional Evaluation of Rhus pariviflora Fruits - A Relish Wild Edible of Uttarakhand. 2019. 10.13140/RG.2.2.19454.64328. 


\section{Information about the authors}

\section{Kozina Zh.L.}

http://orcid.org/0000-0001-5588-4825

zhanneta.kozina@gmail.com

H. S. Skovoroda Kharkiv National Pedagogical

University

Alchevskyh str. 29, Kharkov, 61002, Ukraine

\section{Gushchin S.A.}

zhanneta.kozina@gmail.com

H. S. Skovoroda Kharkiv National Pedagogical

University

Alchevskyh str. 29, Kharkov, 61002, Ukraine

\section{Safronov D.V.}

https://orcid.org/0000-0002-9608-8670

safronovdanil70@gmail.com

V. N. Karazin Kharkiv National University

Svobody sq., 4, Kharkov, 61022 Ukraine

\section{Khrapov S.B.}

sbhrapov@gmail.com

https://orcid.org/0000-0002-7648-1707

National Technical University "Kharkiv Polytechnic

Institute"

st. Kirpicheva, 2, Kharkiv, 61002, Ukraine

\section{Vasilyev Yu.K.}

https://orcid.org/0000-0003-4789-1245

zhanneta.kozina@gmail.com

The National Technical University "Kharkiv Polytechnic

Institute"

ul. Kirpicheva, 2, Kharkov, Ukraine

\section{Інформація про авторів}

Козіна Ж.Л.

http://orcid.org/0000-0001-5588-4825

zhanneta.kozina@gmail.com

Харківський національний педагогічний університет імені Г.С. Сковороди;

вул.Алчевських 29, Харків, 61002, Україна

\section{Гущин С.A.}

zhanneta.kozina@gmail.com

Харківський національний педагогічний університет імені Г.С. Сковороди;

вул.Алчевських 29, Харків, 61002, Україна

\section{Сафронов Д.В.}

https://orcid.org/0000-0002-9608-8670

safronovdanil70@gmail.com

Харківський національний університет імені В.Н.

Каразіна

пл. Свободи, 4, Харків, 61022, Україна

\section{Храпов С.Б.}

sbhrapov@gmail.com

https://orcid.org/0000-0002-7648-1707

Національний технічний університет «Харківський політехнічний інститут»

вул. Кирпичева, 2, Харків, 61000, Україна

\section{Васильев Ю.К.}

https://orcid.org/0000-0002-5090-242X

zhanneta.kozina@gmail.com;

Національний технічний університет «Харківський політехнічний інститут»

вул. Кирпичева, 2, Харків, 61000, Україна 